\title{
TELEKI PÁL ÉS A TÉRKÉP
}

\author{
BASSA LÁSZLÓ
}

, Ideje újra felfedezni.

Nem azért mert gróf volt, Nem azért mert Teleki volt, Hanem mert Valaki volt."

Ambrus Katalin

Teleki Pál munkásságát két szemszögbốl is vizsgálhatjuk. Az egyik szempont a kor, amelyben élt. Pályakezdete századunk elejére tehetổ, ehhez az Osztrák-Magyar Monarchia gazdasági, politikai és szellemi vonatkozásban egyaránt élénk közege inspirálóerôvel hatott. Az élete során bekövetkezett további események: az elsố világháború és a birodalom összeomlása, a forradalmak, a Horthy-rendszer ellentmondásos két évtizede, majd a revíziós politika ,,sikere”, végül pedig az ország háború felé sodródása voltak azok a fổbb stációk, melyek mũködését alapvetôen meghatározták. A másik szempont szubjektívebb és Teleki személyes, szerteágazó ambícióival kapcsolatos: életének különbözố szakaszaiban eltérổ mértékben, de egyaránt hangsúlyos szerepet kapott a politikus, a tudós és a pedagógus (utóbbi tanári és fốcserkészi minốségben egyaránt).

Ami Teleki és a térkép kapcsolatát illeti, figyelemre méltó a következổ megállapítása: a térkép nem egyéb egy módszernél. Amint az a jelen cikkbốl is ki kell derüljön, mindhárom tevékenységéhez elengedhetetlenül szükségesnek tartotta a térkép használatát: politikusként mint bizonyíték erejũ dokumentumot az érveléshez, tudósként mint a földrajzi szintézis megjelenítési eszközét (ezzel kapcsolatban rámutatott: a megoldás a kérdés feltevésében rejlik, utána a térkép már a közlés formája), oktatóként pedig mint tanítási segédeszközt.

A 19. század végén lezárulóban volt a geográfia felfedezésekkel fémjelzett hôskorszaka. Az expedíciós tevékenység elérte tetổpontját, ugyanakkor világossá vált, hogy a hagyományos leíró földrajz át kell adja helyét az oknyomozó, összefüggést keresổ irányzatnak. A természeti földrajzban ezt a richthofeni iskolát id. Lóczy Lajos honosította meg Magyarországon. A modern gazdasági földrajz csak késốbb fejlődik ki a század második felében megjelenổ kereskedelmi földrajzból.

A térképezés fejlôdése egyrészt az általános, technikai és gazdasági haladással párhuzamosan, másrészt a földtudományok differenciálódásának, specializálódásának hatására ugyancsak felgyorsult. A Monarchia területén ez a katonai és kataszteri térképezésben nyilvánult meg, de a vízszabályozások és lecsapolási munkálatok, birtokrendezések - a vasútépítéshez és a hírközlés fejlôdéséhez hasonlóan - már speciális kartográfiai tevékenységeket is életre hívtak. Az egységes földtudomány ,osztódása” eredményeként megjelentek a tematikus (földtani, így pl. az ásványkincsek elterjedését ábrázoló vagy hidrogeológiai helyszínrajzok, a meteorológiai, talajtani, növényzeti, oceanográfiai stb.) térképek. Az 1890-es évek elején Kogutowicz 
Manó által alapított Magyar Földrajzi Intézet Rt. sorra adta ki az irányítási, oktatási és általános mũveltségi igények kielégítését célzó falitérképeket, földrajzi, közigazgatási és iskolai atlaszokat; ezeknek szerkesztésében a korszak szinte minden jelentôs földrajztudósa szerepet vállalt. Részben a tematikus térképezés céljait szolgálta az Országos Statisztikai Hivatal tevékenysége, amely többek között a tízévenként rendezett népszámlálás eredményeinek feldolgozásáért is felelốs volt.

Az enciklopedikus feldolgozások, a térképezés és statisztika szerepének felértékelổése ismételten felvetett általános elméleti kérdéseket. A determinizmus és posszibilizmus közötti dilemma abban állt, hogy - bár a természeti környezet biztosítja az élettevékenységhez szükséges feltételeket, ezért a fejlốdésben játszott szerepe releváns - az ember mégis önállóan formálja környezetét. A vita megoldására a regionalizmus vállalkozott, amennyiben ahelyett, hogy a földfelszíni jelenségekre általános érvényư magyarázatot keresett volna, inkább az egyes területek sokoldalú és részletekbe menô, retrospektív elemzésére, a régiókon belüli összefüggések feltárására vállal kozott, a hangsúlyt a területi egységek egyedi voltára helyezve. Teleki Pált a regionalizmus kiemelkedố képviselổjeként tartjuk számon. Kiváló természet- és társadalomtudományi felkészültsége, széles nemzetközi ismeretei és áttekintése predesztinálta arra, hogy a Föld különbözổ adottságokkal rendelkezố és történelmi fejlődésen keresztül ment régióit a földrajzi szintézis módszerével vizsgálja és tapasztalatait a legkülönbözóbb (ismét csak: politikai, tudományos és oktatási) fórumokon közzétegye.

Teleki tudományos gondolatait meglehetôsen bonyolult formában foglalta össze, ezért ritkán idézik. Gyakran emlegetik azonban A gazdasági élet földrajzi alapjai c. munkájának mottóját: „Térképpel a kezünkben olvassunk! Térképről tanuljunk! Ne egy, de sokféle térképen gyakoroljuk ismételten a térképolvasást!"

Teleki számára a térkép kettổs funkciója evidencia volt: egyaránt használta a tudományos vizsgálódás eszközeként és az eredmények megjelenítéséhez. Tulajdonképpen térképtörténeti mú, az 1909-ben napvilágot látott Atlasz a japáni szigetek cartographiájának történetéhez c. munkája tette nevét nemzetközileg elismertté. Felhivás Magyarország kartográfiájának ügyében c. cikkébốl (1911) kitủnnek olyan látszólag ellentétes, mégis igen fontos tulajdonságok, melyek minden térképész figyelmébe ajánlhatók: az adott probléma nagyvonalú áttekintése és a célnak megfelelố aprólékos munkavégzés. Amikor ugyanis felkérték az Alföld történetének megírására, felhívta a figyelmet a térképes anyagok összegyưjtésének, rendszerezésének és nyilvántartásuk egységesítésének szükségességére, ide értve a legváltozatosabb tartalmú és területi áttekintésû (megyéket, vidékeket, uradalmakat ábrázoló) helyszínrajzokat.

A magyar szakirodalomban mindmáig egyedülálló akadémiai székfoglalójában A földrajzi gondolat története (1917) külön fejezet foglal kozik , ,a térkép feladatával, viszonyával a földrajzhoz és egyéb tudományokhoz". Olyan alapelveket szögezett le ebben a munkájában, amelyekhez egész munkássága során ragaszkodott. Felfogása szerint ugyanis az egyes jelenségek elhelyezkedését (lokáció) és elterjedését (disztribúció) bemutató térképek csupán kartogrammoknak tekintendők, nem pedig földrajzi térképeknek. Utóbbiak ismérve ,,több különböző jelenség kapcsolatos feltüntetése". Példának botanikai (jelenlegi fel fogásunk szerinti tematikus) térképeket sorol fel (szisztematikai egységeket ábrázoló, növénytörténettel foglalkozó vázlatok, a Földet és országokat bemutató flóratérképek stb.), melyek közül a növényközösségeket ábrázolókat tartja a leginkább földrajziaknak, ,topográfiához való simulásuk” okán. Alapvetố 
megállapítása továbbá, hogy a földrajz tárgya a földfelszín élete, és hogy egy térkép annál jobb, minél több bonyolult életjelenséget képes egyezményes jelek, színek, árnyalatok segítségével megjeleníteni. Leszögezi: a földrajzos valódi segítỏeszköze a százezresnél nagyobb léptékũ (topográfiai) térkép. Minél nagyobb ugyanis a méretarány, annál kisebb, ezáltal egyénibb arculatú területet képes a térkép ábrázolni. És fordítva: a méretarány csökkenésével elốtérbe kerül az általánosítás és a térképek tartalmi differenciálódása, megjelennek az egyes jelenségeket ábrázoló (mai szóhasználattal élve analitikus) térképek, melyek közül az orográfiai, klimatológiai, oceanográfiai, hidrográfiai, zoo- és phytogeográfiai térképeket említi.

Ugyanebben a tulajdonképpen igen rövid fejezetben azt írja, ,,legszívesebben látja” olyan tájak térképét, , ,melyek tudományos szempontból, mint karakterisztikus tájak, különleges érdeklốdésnek tárgyai, vagy különlegesen jó példák”. Ezt a felfogást ma problémaközpontúságnak vagy problémaérzékenységnek neveznénk, és a modern atlaszokban (Alexander, Diercke), különösen a környezeti kihívásokkal (komplex hasznosítás, szennyezettség, árvízvédelem, sivatagosodás stb.) kapcsolatban találkozunk ilyen térképekkel.

Ezekhez a gondolatokhoz tér vissza 1922-ben Statisztika és térkép a gazdasági földrajzban c. terjedelmes cikkében. Ismét rámutat: a cél az , individualizálás, különösen a csoportjelenségek individualizálása" (tehát az összefüggõ jelenségek differenciálódása a Föld felszínén) bemutatása. A kartogrammal mint , ,térképelt statisztiká"-val szembeállítja az általa ideálisnak tartott földrajzi térképet. Legszebb példája egy olyan búzatermelési térkép (ami egyébként mindmáig várat magára), melyen a termelési feltételek (optimális horizontális és vertikális határok, klimatikusan és talajadottságok szempontjából legalkalmasabb területek), a termelés intenzitása, a feldolgozás (malomipar), belsổ fogyasztás, a városok termớterülethez viszonyított fekvése, a kivitel aránya és mennyisége kapna helyet. Rámutat, hogy a geográfusnak természetesen a priori ismeretekkel kell rendelkeznie ahhoz, hogy jó térképet szerkesszen: mindazzal a tudásanyaggal rendelkeznie kell, melyet a rokontudományok halmoznak fel, mivel ezeknek feladata az analitikus vizsgálódás, a geográfusé pedig a szintézis. Teleki kutatási módszerét az ok-okozati kapcsolatok keresése, genetikus megközelítés uralta, fölényes természet-és társadalomtudományi ismeretei lehetôvé tették azt, amit manapság dinamikus megközelítésnek nevezünk. Amikor Kalifornia leírásakor rámutat a 19. században bekövetkezett földhasznosítási változásokra (1848-ig állattenyésztés, 1864-1880 között gabonatermelés, attól kezdve gyümölcstermesztés), ezt írja: ,,a térképnek lehetôleg érzékelhetôvé kell tenni azt, hogy annak a területnek a természeti viszonyai milyenek és ma ezen a területen ezt termelnek". A természetes termelô és fogyasztó tájak bemutatását éppen a közigazgatási beosztás ellenében tartotta fontosnak, bár kénytelen elismerni: , ,'gy van szükség az adatokra és így vitathatatlanok a határok. Ezáltal homogén gazdasági területek szétvágatnak, heterogének egységbe foglaltatnak". És következik a példa: Bihar megye síkvidéki, dombos-völgyes és hegyvidéki területeinek szétválasztása, differenciálódásuk a gabonatermelés, legelốterületek, állatállomány szempontjából, vagy - a kedvenc észak-amerikai területról vett példa - a Kentucky-Tennessee vidék különleges blue-grass övezetének privilegizált helyzete tágabb környezetében. A geográfus feladata tehát az egyszerũ statisztikából gazdaságföldrajzi statisztikát készíteni, ugyanis , akkor nevezhetổ egy térkép joggal gazdaságföldrajzi térképnek, ha gazdaságföldrajzi feladatot old meg". Le is ír egy ilyen problémát. Venezuelában a század elején hatalmas legelôterületek álltak rendelkezésre, de a csapadék a nagyarányú állattenyésztéshez kevésnek bizonyult. Ezért ha- 
talmas víztározók építésébe kezdtek. A tervezéshez (Teleki szerint) 1:1.000.000 méretarányú térképre van szükség a legelôterület színezéssel történổ ábrázolásával, a csapadékeloszlás bemutatásával (pontmódszerrel, szezonális eloszlásban), a folyók vízhozamának (a nyári és téli félévben), esetleg izohipszák, izotermák feltüntetésével. A megoldás tehát a kérdések feltevésében már eleve benne rejlik; utána a térkép már csak a közlés egyik (a szöveges, képi, táblázatos módszer melletti) formája: , ,a nemzetgazda (döntéshozó) joggal várja a geográfustól, hogy a természeti okokat közölje".

Ekkorra Teleki több megrázkódtatáson is túlesett, 1918 októberében, amikor világossá vált a monarchia széthullása, élére állt egy nagyszabású térképszerkesztési munkának, melyben több tucat szakember, vagyis földrajztanár, statisztikus, hivatalnok vett részt. Ebben a tevékenységben a térképnek erốsen alkalmazott jellege domborodott ki: a 27 lapból álló gyưjtemény arra kellett, hogy az 1920-as párizsi béketárgyalásokon a magyar állásfoglalás érveit bizonyítsa, annak mellékleteként. Közülük leghíresebb a Carte rouge lett; érdemes azonban ennek kapcsán az etnikai térképnél mint müfajnál hosszasabban elidốzni és más ilyen lapokra is hivatkozni, csupán egy mondatban utalva arra, hogy éppen a nemzetiségek Kárpát-medencén belüli, igen változatos formában megnyilvánuló keveredése irányította a figyelmet az ilyen típusú területek differenciált közigazgatási megközelítésére, és politikai, gazdasági, nyelvi kompromisszumok megkötésének szükségességére.

Amerikai elóadásai között 1921-ben a Williamstown-i Egyetemen hangzott el a Nemzetiségi kérdés - a geográfus szemszögébốl címư. Itt hivatkozik az 1910. évi népszámlálás alapján 1:200.000 méretarányban megszerkesztett térképekre, ezeknek is a Bánáttal foglalkozó területeire. Csak ilyen, jól megválasztott méretarány és ábrázolási módszerek segítségével derülhetett fény az itteni nemzetiségi keveredés specifikumára. A térkép fekete-fehér változatában az egyes községek közigazgatási határain belül elhelyezett, a belterületi népesség számát jelölõ 500 fốt jelképezô nagyobb körök szerepelnek, melyeket a külterületi népességre utaló 50 fốt ábrázoló kisebb körök vesznek körül; a körök belsô satírozása a nemzetiségi hovatartozásra utal. A térkép tanúsága szerint az akkor viszonylag egyenletesen megoszlott etnikumok (román $30 \%$; német $27 \%$; szerb $20 \%$; magyar $17 \%$; egyéb $6 \%$ ) úgy , keveredtek”, hogy a több mint 400 községbôl 300 -ban $80 \%$-ot meghaladta a domináns nemzetiség aránya, viszont ezek a ,tiszta" falvak tökéletes keveredésben találhatók meg a Bánáton belül. A történelmi Magyarország területét ábrázoló Carte rouge ezzel szemben arra épült, hogy az intenzíven benépesült vidékeknek a négyzetkilométerenkénti 100 fốt megközelítôn népsürűségét és a térkép 1:1.000.000 méretarányát használta ki. A domináns nemzetiség mellett így lehetôség nyílott a kisebbségek elhelyezésére, koncentrálódásuk vidékein (négyzetek, téglalapok, háromszögek, foltok formájában) a területtartás olyan következetes érvény re juttatásával, hogy a térképen minden beszínezett négyzetmilliméter 100 fốnek felel meg az adott etnikumból, ugyanakkor a csaknem néptelen területek (felszíni vizek, mocsarak, hegyvidékek, homokos, szikes vidékek) fehéren maradnak. Egyértelmứ, hogy az ilyen kombinált etnikai és népsũrũségi ábrázolás a közel tízmilliónyi magyarság érdekeit volt hivatott érvényesíteni a közel hárommilliónyi románság, 2-2 millió fôs németség és szlovákság, a fél-fél milliót számláló szerbek, rutének és a többi kisebb etnikum ellenében. Szerepelt ebben a térképgyũjteményben továbbá egy nemzetiségi ponttérkép 1:900.000 méretarányban, ahol a különbözố színũ pontok mindegyike 1.000 fởt jelölt, és még számos egyéb népességgel foglalkozó lap (pl. a moldvai csángókról). Több mint másfél évtizeddel késốbb 
Bassa László : Teleki Pál és a térkép

Tér és Társadalom 4. évf. 1990/3-4. 175-183. p.

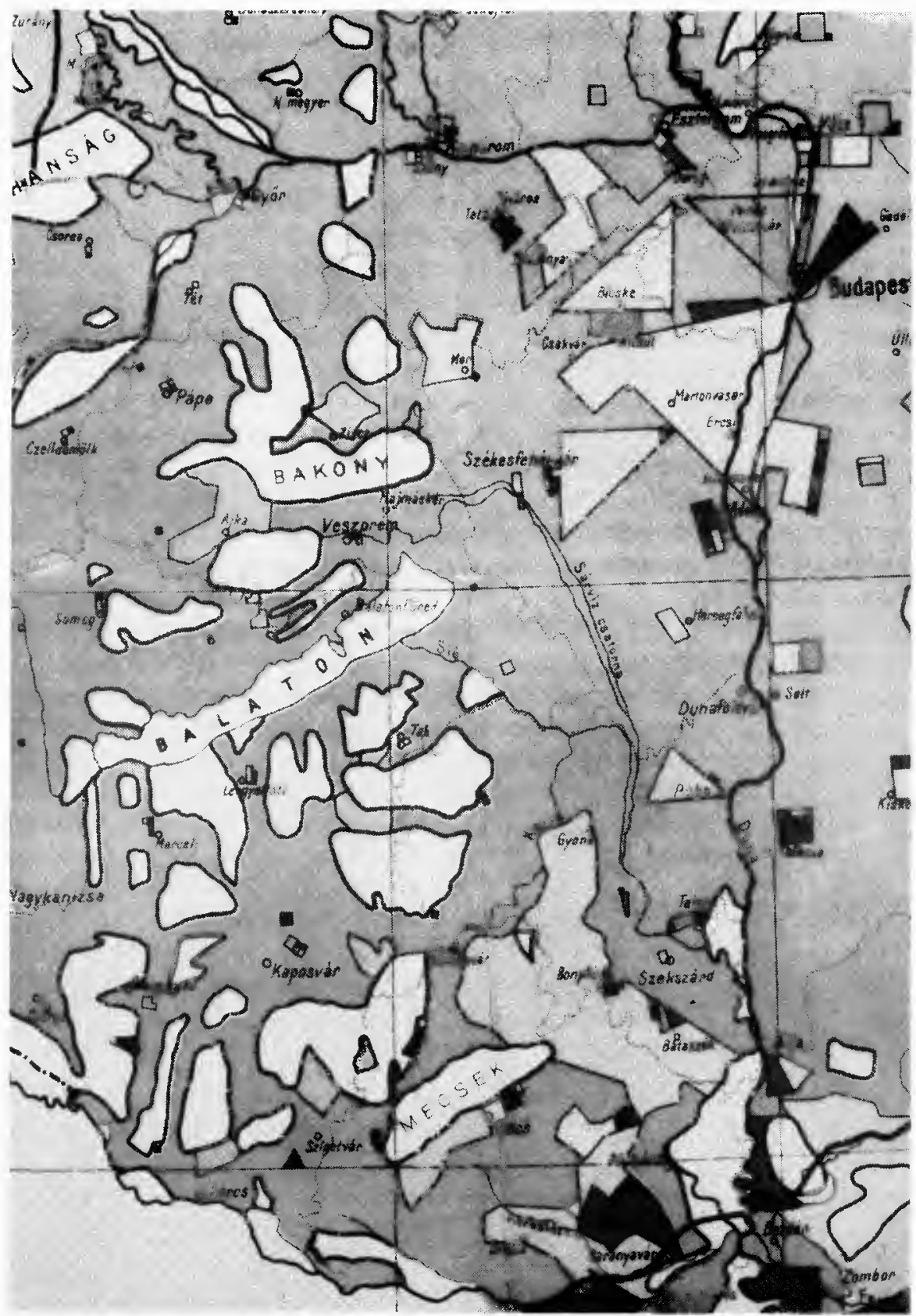

A 'Carte rouge' egy részlete 


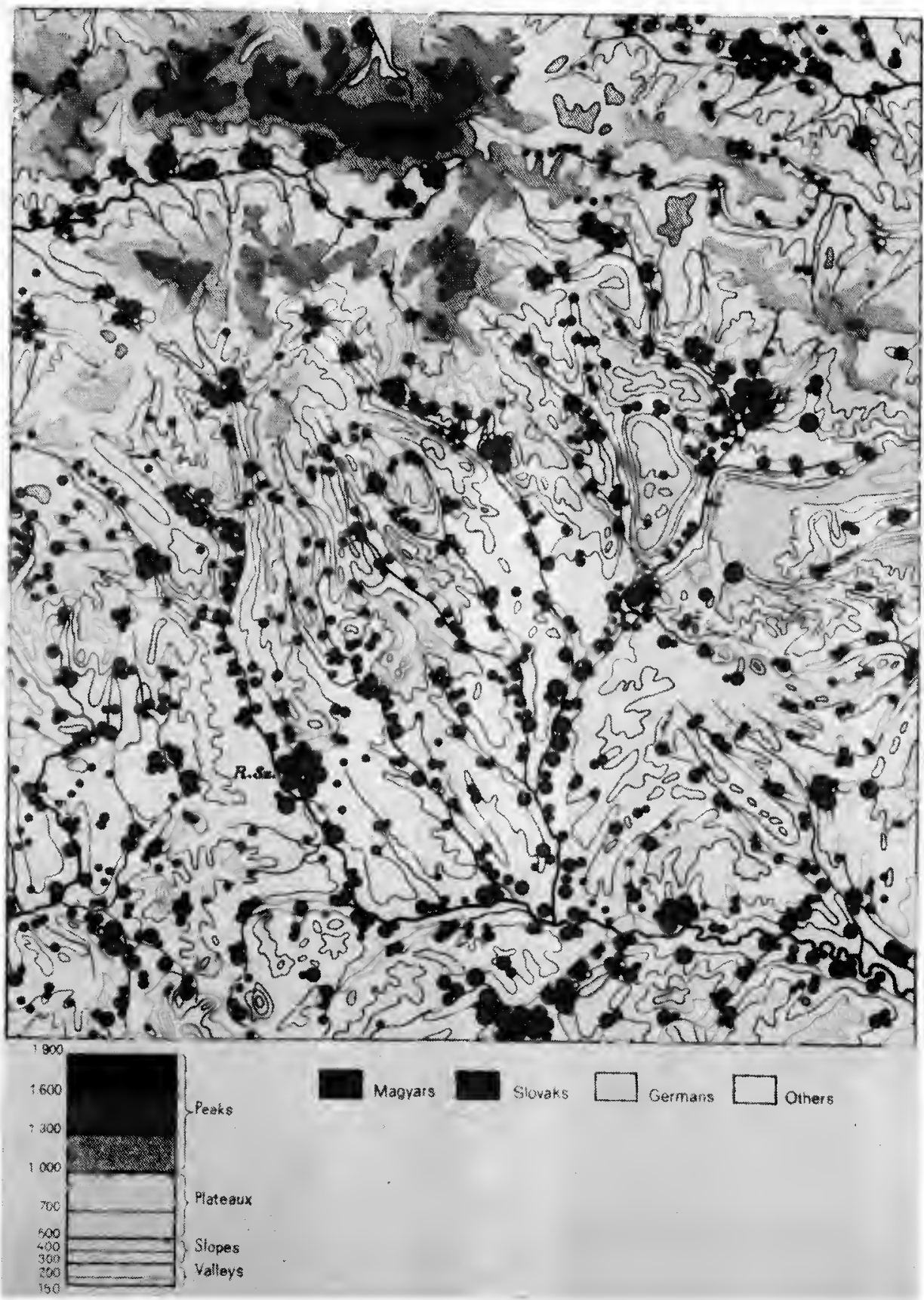

Térkép a 'The different types of ethnic mixture of population' (A népesség etnikai keveredésének különbözó típusai) c. kiadványból 
etnikai térképezési tapasztalatait (a moszuli térségben szerzetteket beleértve) Rónai Andrással adja közre The different types of ethnic mixture of population címmel, melynek ismertetése külön cikket érdemelne.

A béketárgyalásokhoz készített térképes anyag egyéb érdekességekkel is szolgál, így pl. VIII. melléklete tulajdonképpen egy kötetnyi térkép az ország gazdasági életérốl: annak természeti alapjairól, a népességrổ és mũveltségrốl, a kereskedelemrôl és szállitásról, az energiahelyzetrôl és a mezôgazdasági, erdészeti, bányászati és ipari termelésrốl. Olyan térképeket is megtalálunk ebben, amelyeket az utóbbi 40 év hazai berendezkedése átmenetileg feleslegessé tett és a jelenlegi ,,modernizálás" ismét életre hívott; a bank- és pénzintézetekrốl, az egyenes adókról stb. Más térképek (bizonyára örökre) érvényüket vesztették, bár az írástudók aránya helyett a népesség iskolázottsági foka és a közmủvelôdés helyzete az, ami jelenleg fokozott aggodalomra adhat okot Magyarországon.

A Kárpát-medence problémájának átfogó (történelmi, gazdasági, földrajzi) nemzetközi ismertetését Teleki létfontosságú feladatnak tartotta, és 1919-ben kis füzetet jelentetett meg Short notes on the economical and political geography of Hungary (Rövid megjegyzések Magyarország gazdasági és politikai földrajzához) címmel. A közzétett térképek (természetföldrajzi régiók, népsứrűség, talajok, várostipológia, kereskedelmi utak a 14-15. században, csapadék) méretaránya kicsiny, 1:3.000.000 és 1:5.000.000 között váltakozik, külön-külön, a kartogrammokat tartalmazó ábrákkal és a szöveges résszel együtt azonban a földrajzi szintézis szép példái (a talajtérképen két zonális, két-két intrazonális és azonális talajféleséget különítenek el, az évi csapadékelosztást izovonalakkal ábrázolják $100 \mathrm{~mm}$-enként, a településtípusok esetében a gażdasági [termelési, kereskedelmi, közlekedési] jelleg a mérvadó). A szerzô felfogása szerint a kilenc, természeti viszonyait és gazdasági szerepkörét tekintve markánsan elkülöníthetố régió (Nagyalföld, Dunántúl, Kisalföld, Felvidék, ÉK-i Kárpátok, K-i és D-i Kárpátok, Erdélyi Szigethegység, Mezôség és Karsztvidék) azokat összekötố, nem pedig elválasztó átmeneti régiókon keresztül érintkezik egymással. Kimutatja, hogy a síkságoknak, dombságoknak és hegyvidékeknek ebben a találkozási övezetében (vásáröv) a 19. század utolsó és a 20. század elsố évtizedében a bevándorlás mintegy negyedével haladta meg az elvándorlást. Trianon után csak az első három nagytáj maradt meg az ország határain belül. Érdekes, hogy az átmeneti zóna egyes darabjai utóbb önálló makrorégiókká avanzsáltak (Dunántúli-középhegység, Északiközéphegység, Alpokalja, a jelenlegi tájbeosztás szerint). Egy mára már szinte elfeledett módszer éled újra a hasábdiagrammokon: a gabonafélék, kukorica és burgonya ábrázolásakor a hasábok alapja a bevetett területtel (10 ezer ha), magassága az átlaghozammal (q/ha) arányos, következésképpen köbtartalma a bruttó termelést adja. Mũfajilag nehéz lenne megmondani, mi ez a brossúra: rövid ismertetổ Magyarországról, térképes- és ábramellékletekkel, vagy miniatlasz szöveges magyarázóval; de ez talán nem is fontos, amikor szöveg és kép ilyen szervesen összefügg. Hiszen Telekinél ez mindig így van: a népvándorlási útvonalakhoz az éghajlati kontinentalitásț ábrázoló térképet szerkesztetett, ezzel kívánva bizonyítani, hogy a magyar törzsek a Káma-vidéktốl a Kárpát-medencéig végig a sztyeppe és erdôs sztyeppe határán vándoroltak, és nem véletlenül telepedtek meg ezen, az ôshazára természeti viszonyaiban Európában leginkább emlékeztetố tájon, éppen úgy, ahogy az USA-ba kivándorló etnikumiok is azonos klímaterületeket kerestek letelepedésükhöz. 
A Teleki nevével fémjelzett iskola képviselơi (Köpeczi Nagy Zoltán — éghajlat és növényföldrajz, Koch Ferenc - gazdasági földrajz, Kádár László - tájkutatás, Hantos Gyula - népességföldrajz, Kreybig Lajos - talajtérképezés, Gyốrffy István - néprajz, Rónai András - politikai földrajz) kutatásaik során állandóan alkalmaztak kartográfiai módszereket; tudományos eredményeiket számos atlasz, térképsorozat és egyedi térkép ôrzi.

Különösen hasznos visszanyúlni Teleki múveihez manapság, amikor kritikusan szemléljük az ország több mint negyven éves fejlôdését, a voluntarista döntéseket, melyek sok esetben figyelmen kívül hagyták a természeti és társadalmi adottságokból fakadó fejlesztési lehetôségeket, és máss alternatívákat helyeztek elốtérbe. Az ökológiai adottságokhoz jobban alkalmazkodó mezổgazdaság, a környezetkimélổ, saját természeti- és munkaerõ-forrásokra támaszkodó ipar meghonosítása, a közigazgatáson belül a vonzáskörzetek, az önkormányzat fokozott érvényre juttatása, az infrastrukturális fejlesztés elổérbe helyezése a jelen feladatai. Ez annak a Telekiféle gondolatnak a felelevenítése, hogy az a jó politikai irányítás, amely a táj szerves fejlôdését segíti elố (az organizatorikus elem az organikus tényezốk javára munkálkodik). Teleki vállára nagy súllyal nehezedett az a teher, hogy egyszerre volt döntéshozó és kiemelkedổ tudós, ugyanakkor ez adott számára lehetôséget a tudomány maximális támogatására.

A technika fejlődése korunk térképészetére is nagy hatással van. Bizonyos szintetizálást bármennyire furcsán is hangzik - légi és ưreszközökre szerelt szenzorok vagy számítógépek végeznek el az ember helyett. Ezek az eszközök és az általuk biztosított kutatási módszerek fokozott lehetôséget nyújtanak az egymással összefüggésben álló jelenségek és folyamatok felderítésére. A megválaszolásra váró kérdés, illetve megoldandó probléma azonban nem kevesebb, mint fél évszázaddal ezelốtt volt (gondoljunk csak a környezeti válságra), ami azt látszik megerổsíteni, hogy az olyan szellemi tôkére, melyet Teleki Pál és munkatársai a saját korukban képviseltek, manapság, ha lehet, még nagyobb szükség van. A közel hetven éve leírt szavak még most sem vesztették el aktualitásukat; sok még az olyan nyitott kérdés, melyre ,,a dicséretesen sokasodó, de még egészben kevés részletkutatás máig sem tud kellõ tudományos kritikával átszũrt és felépített válaszokat adni".

\section{Irodalom}

A gazdasági élet folldrajzi alapjai, (Koch F. és Kádár L. közremüköđésével, 2. kötet. Budapest) (1936)

A földrajzi gondolat története, Akadémiai székfoglaló. Akadémiai Értesitó 1917. április

Atlasz a Japáni szigetek cartographiájának történetéhez. A Japántól keletre fekvó aranyszigetek felfedezésére 1639-ben kiküldö̈t Quast M. és Tasman J. A. kapitányok hajónaplójának hollandus szövegével és magyar fordításával. Budapest, 1909.

Európáról és Magyarországról, Budapest, 1934.

Felhívás Magyarország kartográfiájának ügyében, Földrajzi Közlemények 1911.

Les négociations de la paix Hongroise. Compte rendu sur les travaux de la délégation de paix de Hongrie a Nevilly $S / S$ janvier a mars 1920 . Tome III/B.

Kish, G. (1988) Paul Teleki 1879-1941. Geographical Studies, Vol. 11. London-New York.

Koch F. (1958) Teleki Pál gazdaságföldrajzi munkásságának bírálata. MTA Társ. Tud. Oszt. Közl. 1956/VIII. 1.

Memorandum on the Different Types of Ethnic Mixture of Population, (Társszer.: A. Rónai) Internat. Studies Conf. Budapest: 1937.

Short notes on the economical and political geography of Hungary. Budapest, 1919.

Statisztika és térkép a gazdasági földrajzban. Földrajzi Közlemények 1922. 


\section{PAUL TELEKI AND THE MAP}

\section{LÁSZLÓ BASSA}

The activity of Count Paul Teleki (1879-1941), the reknown Hungarian geographer, can be observed from a dual viewpoint. The first one is inseparable from the historical period in which he lived. His career started in the beginning of our century when he was inspired by the lively economic, political and spiritual atmosphere of the Austro-Hungarian Monarchy. Further events also occurred during his lifetime, namely the First World War, the collapse of the empire and the subsequent revolutions, two decades of counter-revolution and the "success" of policy aiming at the restoration of some of the territories Hungary had lost after the war, finally the drift of the country towards the Second World War, were the crucial points determining his activity. The second aspect is a more subjective one and is related to Teleki's far-reaching personal ambitions, since in various periods of his life, although to a different extent, he acted as a politician, a scolar and a teacher.

As a politician (among others, prime minister of Hungary in 1920 and from 1939 to 1941) he extensively used maps, compiled by himself, when arguing over different issues, especially during the negotiations of the Trianon peace treaty and in the revisionist campaign, involving ethnic maps based on the 1910 census of the Monarchy (the famous Carte rouge).

For Teleki the scholar maps were primarily the tools for geographic synthesis. He considered analytic maps mere "mapped statistics" still indispensable for the compilation of more sophisticated types of maps: the complex and synthetic ones in a contemporary sense. He was an outstanding representative of regionalism in geography, which, instead of searching for global regularities of phenomena, aimed at detailed and retrospective diagnoses of certain segments on the surface of Earth (regions, landscape units etc.) and of relationships between them, putting a strong emphasis on their uniqueness. According to Teleki, location and distribution of phenomena shown on maps should primarily reveal this interrelationship.

Paul Teleki, university professor of economic geography had a slogan, written as a motto to his book, the Geographical bases of economic life, a transcript of his lectures by pupils: "Always study with a map by your side! Learn from the map! Practise map reading, not just with one map but with several types of maps!". He brought up a generation of geographers who were closely attached to cartography, too.

Translated by the author 